\title{
Çamlıhemşin-Palovit Yaylasının botanik kompozisyonu üzerine bir araştırma
}

\author{
Hüseyin Baykal $^{\mathrm{a}}$ (D), Muhammed İkbal Çatal ${ }^{\text {b,* }}$ (D), Adil Bakoğlua ${ }^{\mathrm{a}}$ (D)
}

\begin{abstract}
Özet: Bu çalışma ile Rize ili Çamlıhemşin ilçesine bağlı Palovit Yaylasının, botanik kompozisyonu, bitkilerin toprağı kaplama oranı ve mera derecesinin belirlenmesi amaçlanmıştır. 2019 yılı içerisinde, yaylanın mera vejetasyonunun klimaks evresine ulaştığı Temmuz ayında gerçekleştirilen arazi çalışmaları sonunda, Lup metodu ile alınan hatlardan, 112 bitki örneği toplanmıştır. 22 cins ve 15 familya ait toplam 25 taksonun, 10 tanesinin monokotil, 15 tanesinin ise dikotil olduğu belirlenmiştir. Araştırma alanında, mera kalite derecesine göre meraların durumunun tespit edilmesinde botanik kompozisyon bakımından önemli olan familyalardan, Poaceae familyası 6 takson ve \% 54.98'lik bir oran ve Fabaceae familyas 1 takson ve \% 2.88 gibi son derece düşük bir oranla temsil edilmektedir. Araştırma alanındaki diğer 18 taksonun dahil olduğu 13 familyanın toplam botanik kompozisyon oranının \% 42.14 olduğu saptanmıştır. Araştırma sonucunda, bitkilerin toplam toprağı kaplama oranının \% 70.75, mera durumunun ise hesaplanan 2.383'lük mera derecesine göre zayıf olduğu belirlenmiștir
\end{abstract}

Anahtar kelimeler: Çamlıhemşin-Palovit yaylası, Toprağı kaplama oranı, Botanik kompozisyon, Mera durumu

\section{A research on the botanical composition of Çamlıhemşin-Palovit Plateau}

\begin{abstract}
The aim of this study was to determine the rate of botanical composition, canopy covering of plants and the degree of pasture.of the Palovit plateau of Çamlıhemşin district of Rize province, In 2019, 112 plant samples were collected from the lines taken by the Loup method as a result of the field studies carried out in July, when the plateau reached the climax stage of the pasture vegetation. A total of 25 taxa belonging to 22 genus and 15 families were identified as 10 monocotyl and 15 dicotyl. In the research area, from the families are important in terms of botanical composition in determining the status of pastures according to the quality of pasture is represented by Poaceae family 6 taxa and $54.98 \%$ and Fabacaeae family a very low with 1 taxa and $2.88 \%$. In the research, total botanical composition ratio of 13 families including 18 other taxa was found to be 42.14 $\%$. As a result of the research, $70.75 \%$ of the total canopy cover rate of plants; pasture were found to be weak according to the calculated 2.383 pasture degree.
\end{abstract}

Keywords: Camlıhemşin-Palovit plateau, Canopy cover rate, Botanical composition, Pasture status

\section{Giriş}

Hayvanların beslenmesinde ihtiyaç duyulan en önemli yem kaynakları çayır mera alanlarından karşılanmaktadır (Aydın ve Uzun, 2002). İhtiyaç duyulan yemin \% 30'u (Gökkuş, 1994) ve ülkemiz hayvan varlığının bir yılda tükettiği besinlerin ham proteinin \% 68'i, nişastanın da \% 62'si çayır ve mera alanlarından karşılanmaktadır (Okatan ve Yüksek, 1997; Babalık ve Sarıkaya, 2015). Ayrıca çayır mera alanlarının yem kaynağı olmasının yanında kültür bitkilerinin gen kaynağı olması, biyolojik çeşitliliği sağlaması ve toprağı erozyona karşı koruması gibi birçok yararı da bulunmaktadır (Carlier vd., 2005). Hayvanlar, beslenmelerinde daha çok otsu bitkileri tercih etmektedirler. Otsu bitkilerden buğdaygillerin karbonhidrat yönünden ve baklagillerin protein yönünden zengin olmasından dolayı hayvanlar tarafindan tüketildiğinde dengeli bir beslenme sağlanmaktadır. Ayrıca mera vejetasyonunda buğdaygil ve baklagil familyalarına ait taksonların yoğun olarak bulunması hem mera kalite derecesini olumlu yönde etkilemekte hem de hayvanlar bu familyalara ait bitkileri daha çok tercih etmektedirler.
Geçmiş yıllardan beri sürekli olarak ülkemiz meralarında aşırı ve erken otlatma yapılması ve ıslah ve bakım işlemlerinin uygulanmaması nedeniyle meraların bitki örtüsü bozulmuş ve ot verimleri azalmıştır (Yavuz ve Sürmen, 2016; Sürmen ve Kara, 2018). Bu durum hayvanların ihtiyaç duyduğu yem açığı açısından büyük sorun oluşturmaktadır. Bu sorunun çözülebilmesi için ot verimi ve kalitesi düşmüş meraların islah edilerek verim ve kalitesi yükseltilmelidir. Ancak mera ıslahında başarılı olmak için sslahı yapılacak meranın vejetasyonu bilinmelidir. Meranın vejetasyonu ise o meraya ait botanik ve floristik kompozisyon çalışmaları yapılarak belirlenebilmektedir. Çayır ve mera bitki topluluğunda bulunan bir merada yer alan bütün taksonların tamamı floristik kompozisyon olarak, birim alanda bulunan takson sayısı ise botanik kompozisyon olarak ifade edilir.

1940 'l 1 yıllarda ülkemizde 45 milyon ha olan mera alanı varlığı, günümüzde 14.6 milyon ha (TÜİK, 2019) ve Rize ilinde 45.332 ha çayır-mera alanı bulunmaktadır (RİTOM, 2018).

Ülkemizde son yıllarda yapılan botanik kompozisyonla ilgili çalışmalara baktığımızda; İspirli vd., (2016)

\footnotetext{
$\bowtie$ a Recep Tayyip Erdoğan Üniversitesi, Pazar Meslek Yüksekokulu, Bitkisel ve Hayvansal Üretim Bölümü, Rize, Türkiye

b Recep Tayyip Erdoğan Üniversitesi, Ziraat ve Doğa Bilimleri Fakültesi, Tarla Bitkileri Bölümü, Rize, Türkiye

@* Corresponding author (İletişim yazarı): muhammed.catal@erdogan.edu.tr

$\checkmark \quad$ Received (Geliş tarihi): 13.09.2019, Accepted (Kabul tarihi): 25.03.2020
}

Citation (Atıf): Baykal, H., Çatal, M.İ., Bakoğlu, A, 2020. Çamlıhemşin-Palovit Yaylasının botanik kompozisyonu üzerine bir araştırma. Turkish Journal of Forestry, 21(2): 136-140. DOI: $10.18182 /$ tjf.619962 
Kastamonu ili, Taşköprü ilçesine bağlı 12 köyün doğal meralarında yapılan çalışmalarda bitkiyle kaplı alan oranı ortalamas1 \% 83.34, meraların 1 adedi "İyi", 5 adedi "Orta" ve 6 adedi ise "Zayıf" mera durumu olduğu; Babalık ve Ercan, (2018) çalışma alanının bitkiyle kaplı alan değeri \% 51.2, mera alanının botanik kompozisyonunun buğdaygiller, baklagiller ve diğer familyalar oranı sirasıyla \% 44, 23, 33 şeklinde oluştuğu; Sürmen ve Kara, (2018) ağırlığa göre botanik kompozisyonda buğdaygillerin oranı \% 37.09, baklagillerin oranı \% 4.24 ve diğer familya bitkilerin oranı \% 58.67 bulduğu; Çınar vd., (2019) meralarda bitki ile kaplı alanda ortalama olarak buğdaygillerin oranı \% 36.9, baklagillerin oranı \% 22.0 ve diğer familya bitkilerin oranı $\%$ 41.1, mera kalite derecelerinin 2.40-3.92 arasinda değiştiği ve meraların durum sınıfının zayıf olduğu; Bakoğlu vd., (2019) Rize ili Handüzü yaylasında yaptığı çalışmada, toprağı kaplama oranını \% 82.4, toprağı kaplama alanına göre buğdaygillerin botanik kompozisyondaki oranını \% 33.37, baklagillerin oranını \% 5.75 ve diğer familyaların oranını \% 60.88 bulduğu ve 2.456 mera kalite derecesi ile meranın durumunun zayıf olduğu; Çatal vd., (2019) Rize ili Ovit yaylasında yaptı̆̆ çalışmada, toprağ kaplama oranını \% 63.4; botanik kompozisyonda buğdaygillerin oranı \% 39.35, baklagillerin oranı $\% 6.61$ ve diğer familyaların oranı da \% 54.04 olarak tespit ettiğini ve 1.976 mera derecesi ile meranın durumunu çok zayıf bulduğu araştırıcılar tarafından belirtilmiştir.

Rize ilinde bitkisel çeşitliliğin ortaya konmasını amaçlayan floristik çalışmalar (Çobanoğlu, 2012; Baykal ve Atamov, 2016; Baykal ve Atamov, 2017; Süzen, 2017; Baykal ve Atamov, 2018; Baykal vd., 2018 ve Baykal, 2019) mevcut olmasına karşın Palovit yaylasının botanik kompozisyon, toprağı kaplama oranı ve mera kalite derecesinin belirlenmesini amaçlayan herhangi bir çalışma bulunmamaktadır. Çalışmanın temel amacı Palovit yaylasının bu kriterlerin tespit edilmesidir.

\section{Materyal ve yöntem}

\section{1. Çalışma alanı}

$\mathrm{Bu}$ araştırma 2019 yılında Rize ili Çamlıhemşin ilçesine bağlı deniz seviyesinden ortalama $2330 \mathrm{~m}$ yükseklikte $\left(40^{\circ}\right.$ $52^{1} 11^{11} \mathrm{~N}, 41^{\circ} 05^{1} 11^{11} \mathrm{E}$ ) ve ilçeye $15 \mathrm{~km}$ uzaklıkta bulunan Palovit yaylasının yaklaşık 20 da'lık alanında ölçüm yapılmıştır (Şekil 1). Çalışma sahasından çekilen bazı fotoğraflar Şekil 2'de verilmiştir.

Araştırma alanının uzun yıllar sıcaklık ortalaması, yağı̧̧ miktarı ve nisbi nemi sirasiyla $14.3^{\circ} \mathrm{C}, 2296 \mathrm{~mm}, \% 80$ olarak belirlenmiştir (TÜİK, 2019).
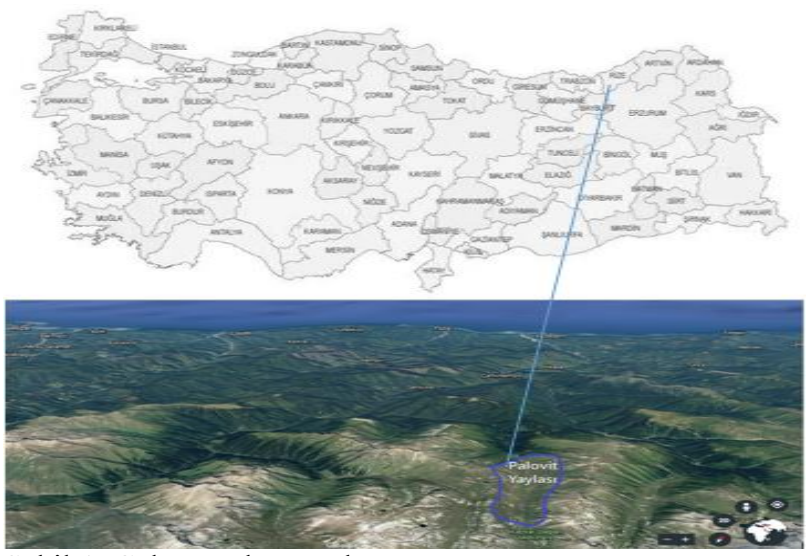

Şekil 1. Çalışma alanının konumu

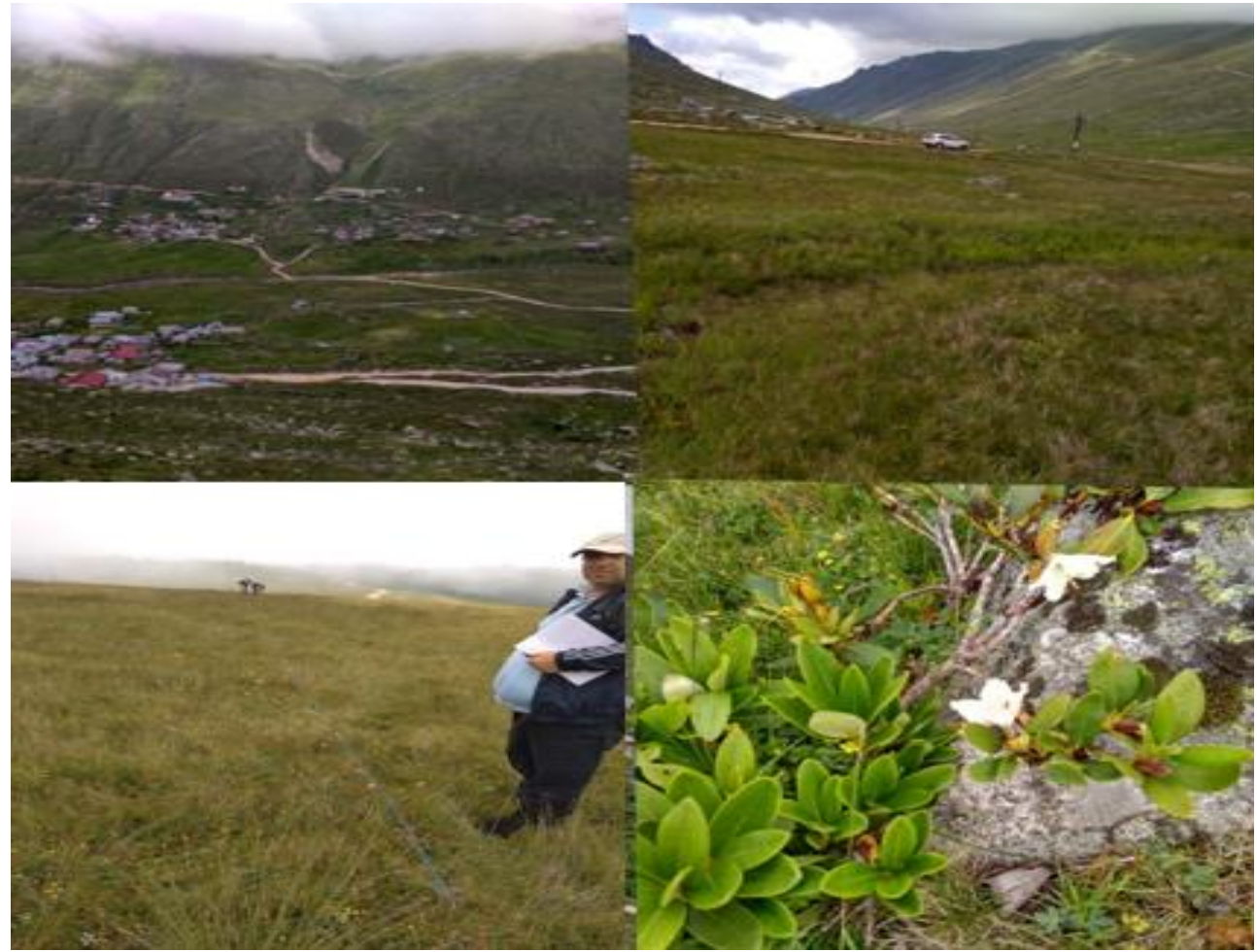

Şekil 2. Çalışma alanından bazı görüntüler 


\subsection{Yöntem}

Arazi çalışmaları 2019 yılında, Palovit yaylası mera vejetasyonunun klimaks safhaya ulaştığı Temmuz ayında gerçekleştirilmiştir. Araştırmanın birinci önemli materyalini bu çalışmalar sonucu toplanan 112 bitki örneği oluşturmaktadır. Her bir takson için en az 2 bitki örneği herbaryum kurallarına göre (Erik vd., 1996) kurutularak kartonlara yapıştırılmış ve Recep Tayyip Erdoğan Üniversitesi Pazar Meslek Yüksekokulu'nda koruma altına alınmıştır. Bitki örnekleri Türkiye ve Ege Adaları Florası (Davis, 1965-1985; Davis vd., 1988; Güner vd., 2000) yardımı ile teşhis edilmiştir. Teşhisi yapılan örnekler, bölgede yapılmış ilişkili (Çobanoğlu, 2012; Baykal ve Atamov, 2016; Baykal ve Atamov, 2017; Süzen, 2017; Baykal ve Atamov, 2018; Baykal vd., 2018 ve Baykal, 2019) diğer çalışmalar ile kontrol edilmiştir. Familya, takson (Türkçe adlar dahil) ve yazar adları sırası ile Güner vd., (2012)'e göre verilmiştir.

Meranın vejetasyon ölçümleri Lup metodu kullanılarak yapılmıştır. Lup çap $2 \mathrm{~cm}$ olan bir halkadır. Bir Lup hattı $20 \mathrm{~m}$ uzunluktadır. Birbirini takip eden iki lup arası ölçüm mesafesi 20 santimetredir. Bu nedenle bir Lup hattında toplam 100 Lup değeri ölçülmektedir. Botanik kompozisyonun belirlenmesinde her bir lup içerisine düşen bitki taksonu ölçüm cetveline kaydedilmektedir. Çalışmanın ikinci en önemli materyalini bu ölçüm cetveli oluşturmaktadır. Lup içerisine düşen, farklı bitki örnekleri bütün organları ile birlikte teşhis edilmek üzere toplanmaktadır. Yaylanın botanik kompozisyonun belirlenmesinde Tosun, (1968)'un belirttiği esaslar dikkate alınarak her bir ana hat üzerinde 10 Lup hat olacak şekilde 5 ana hat ölçülmüştür. Lup ölçümlerinde bitkiye rastlanılan Lup alanlarının, toplam Lup alanına bölünmesiyle toprağı kaplama alanı belirlenmiştir (Gökkuş vd., 1993). Botanik kompozisyonda yer alan bitkilere Gökkuş vd., (1993) ve Bakoğlu (1999)'nun belirttikleri esaslar dahilinde ve TÜGGM (2008)'de bitkilerin yem olarak değerlendirilmesi durumuna göre -1 ile 10 arasında puanlar verilmiş, daha sonra botanik kompozisyondaki oranları ile çarpılarak, tüm taksonlara ait değerlerin toplanmasıyla mera kalite derecesine göre (Çizelge 1), mera durum sınıfı bulunmuştur.

Çizelge 1. Mera durumu skalası (De Vries vd., 1951)

\begin{tabular}{cc}
\hline Kalite derecesi & Mera durumu \\
\hline $8.1-10$ & Çok iyi \\
$6.1-8$ & İyi \\
$4.1-6$ & Orta \\
$2.1-4$ & Zayıf \\
$0.0-2$ & Çok zayıf \\
\hline
\end{tabular}

\section{Bulgular ve tartışma}

Çalışmada tespit edilen takson listesi, familyası, toprağ kaplama ve botanik kompozisyon oranı ve mera derecesi Çizelge 2'de, familyaların toprağı kaplama ve botanik kompozisyon oranları Şekil 3'de, familyalara göre mera dereceleri Şekil 4'de ve familyalara göre takson sayısı Şekil 5 'de verilmiştir.

Çizelge 2'ye bakıldığında çalışılan meranın toplam toprağı kaplama oranı $\% 70.75$, buğdaygiller, baklagiller ve diğer familyaların oranı ise sırasıyla \% 39.0; 2.00; 29.75 olarak belirlenmiştir. Toprağı kaplama alanına göre Poaceae, Fabaceae ve diğer familyaların botanik kompozisyonu sirasiyla \% 54.98; 2.88; 42.14 olarak tespit edilmiştir. Mera kalite derecesi 2.383 değeri ile meranın durumu zayıf olduğu belirlenmiştir. Çalıșılan meranın botanik kompozisyonunda bulunan bitkilerden Poaceae'den Kılotu (Nardus stricta L.) (\% 30.25); Fabaceae'den Aküçgül (Trifolium repens L. var. repens) (\% 2.88) ve diğer familyalardan Beşparmakotu (Potentilla crantzii (Crantz) Fritsch) (\% 10.88) taksonları ilk sırayı oluşturmaktadır. Diğer familyalardan Cyperaceae ve Rosaceae'dan 3'er tane, Ericaceae familyasından 2 tane, diğerlerinden (Apiaceae, Asteraceae, Campanulaceae, Gentianaceae, Onagraceae, Orchidaceae, Plantaginaceae, Polygonaceae, Primulaceae, Ranunculaceae) 1'er tane takson tespit edilmiştir (Şekil 3).

Araştırmadan elde edilen sonuçlar ile diğer araştırıcıların (İspirli vd., 2016; Babalık ve Ercan, 2018; Sürmen ve Kara, 2018; Çınar vd., 2019; Bakoğlu vd., 2019; Çatal vd., 2019) bulguları arasında benzerlik ve farklılıklar bulunmaktadır. Farklılıkların ortaya çıkmasına meraların farklı iklim ve toprak koşulları ve farklı uygulamalardan kaynaklanabileceği belirlenmiştir. Araştırma alanında Kılotu (Nardus stricta L.)'nın çok yüksek bir toprağı kaplama alanı (\% 21.50) ve botanik kompozisyona (\% 30.25) sahip olmas1, türün çok nemli bölgelere adapte olması ve hayvanlar tarafindan yem olarak tercih edilmemesi olarak açıklanmaktadır. Ayrıca Kılotu (Nardus stricta L.)'nun köklerinin, diğer bitki köklerinin toprağı bağlanmasını engelleyecek şekilde yoğun bulunması ve araştırma alanının yer yer döküntü kayalıklarla kaplı olması meranın tür çeşitliliğinin az olmasının en önemli faktörüdür.

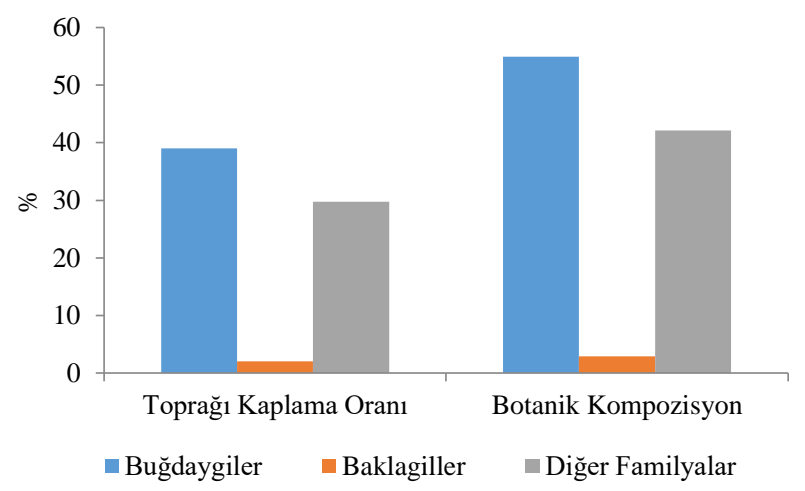

Şekil 3. Familyaların toprağı kaplama ve botanik kompozisyon oranları 


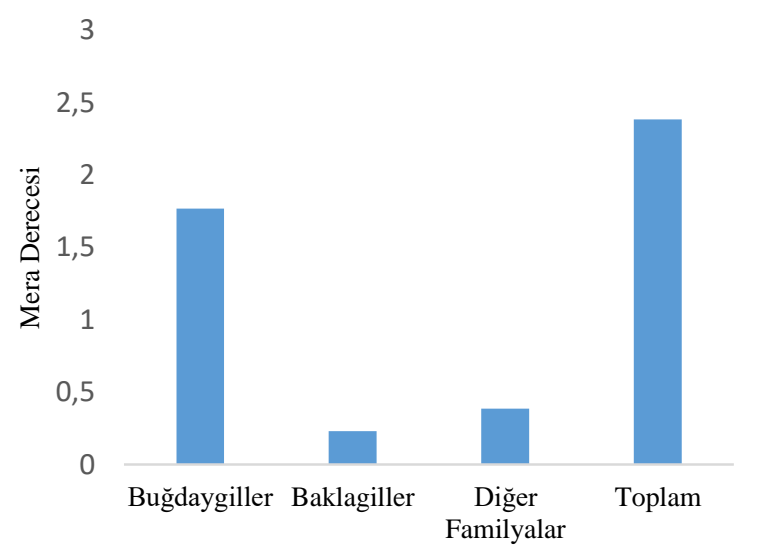

Şekil 4. Familyalara göre mera dereceleri (De Vries vd., 1951)

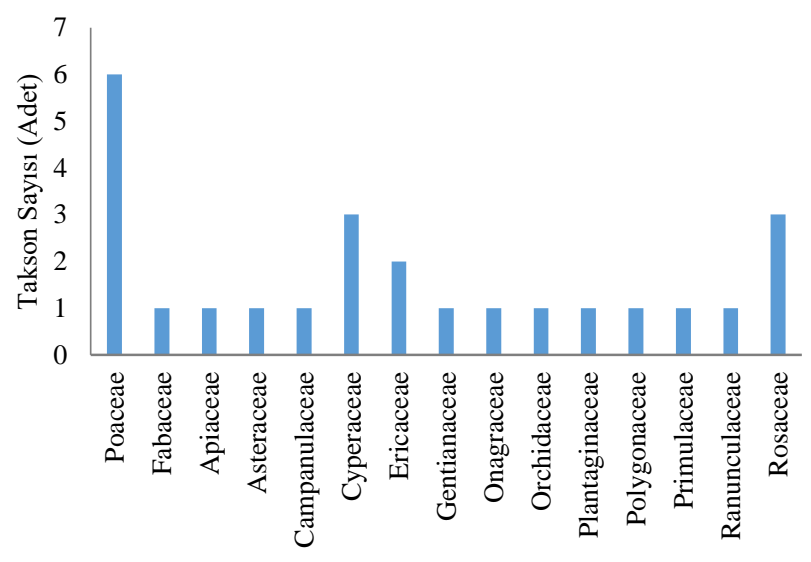

Şekil 5. Familyalara göre takson sayıları

Çizelge 2. Ovit Yaylasının mera alanında bulunan bitkilerin familyaları, taksonları, değer sayıları, toprağı kaplama ve botanik kompozisyon oranları, mera dereceleri

\begin{tabular}{|c|c|c|c|c|c|c|c|}
\hline & Familya & Takson ismi (M / D) & Türkçe ismi & DS & TKO & BK & MD \\
\hline & \multicolumn{7}{|c|}{ BUĞDAYGİLLER } \\
\hline 1 & Poaceae & Anthoxanthum odoratum L. / M & Kokuotu & 0 & 3.50 & 5.00 & 0.000 \\
\hline 2 & Poaceae & Briza minor L. / M & Küçükzembil & 1 & 1.50 & 2.11 & 0.021 \\
\hline 3 & Poaceae & Nardus stricta L. / M & Kilotu & 3 & 21.50 & 30.25 & 0.908 \\
\hline 4 & Poaceae & Phleum alpinum L. / M & Alpitkuyruğu & 4 & 3.00 & 4.27 & 0.171 \\
\hline 5 & Poaceae & $\begin{array}{l}\text { Poa alpina } \mathrm{L} \text {. subsp. } \\
\text { fallax F. Herm. / M }\end{array}$ & Yaylasalkımotu & 5 & 3.25 & 4.61 & 0.231 \\
\hline \multirow[t]{3}{*}{6} & Poaceae & Poa angustifolia L. / M & Darsalkımotu & 5 & 6.25 & 8.74 & 0.437 \\
\hline & & & \multicolumn{2}{|l|}{ Toplam } & 39.00 & 54.98 & 1.767 \\
\hline & \multicolumn{7}{|l|}{ BAKLAGİLLER } \\
\hline \multirow[t]{3}{*}{1} & Fabaceae & Trifolium repens L. var. repens /D & Aküçgül & 8 & 2.00 & 2.88 & 0.230 \\
\hline & & & \multicolumn{2}{|l|}{ Toplam } & 2.00 & 2.88 & 0.230 \\
\hline & \multicolumn{7}{|c|}{ DİĞER FAMİLYALAR } \\
\hline 1 & Apiaceae & Chamaesciadium acaule (M.Bieb.) Boiss. / D & Hamotu & 3 & 2.00 & 2.77 & 0.083 \\
\hline 2 & Asteraceae & $\begin{array}{l}\text { Pilosella hoppeana (Schult.) F.W.Schultz \& Sch.Bip. subsp. } \\
\text { hoppeana / D }\end{array}$ & Gültırnakotu & 0 & 0.75 & 1.02 & 0.000 \\
\hline 3 & Campanulaceae & Campanula collina Sims /D & Çayırçıngırağı & 0 & 0.50 & 0.81 & 0.000 \\
\hline 4 & Cyperaceae & Carex brevicollis DC. / M & Yakalısaz & 3 & 0.75 & 1.02 & 0.031 \\
\hline 5 & Cyperaceae & Carex echinata Murray / M & Kütayakotu & 3 & 2.75 & 3.77 & 0.113 \\
\hline 6 & Cyperaceae & Carex oligantha Steudel / M & Garipsaz & 3 & 2.00 & 2.87 & 0.086 \\
\hline 7 & Ericaceae & Rhododendron caucasicum Pall. / D & Dağkumarı & -1 & 0.25 & 0.35 & -0.004 \\
\hline 8 & Ericaceae & Vaccinium myrtillus L. / D & Ayıüzümü & 3 & 0.25 & 0.34 & 0.010 \\
\hline 9 & Gentianaceae & Gentiana pyrenaica L. / D & Pirgentiyanı & 0 & 0.75 & 1.07 & 0.000 \\
\hline 10 & Onagraceae & Epilobium palustre L. / D & Dereyakısı & 0 & 0.25 & 0.35 & 0.000 \\
\hline 11 & Orchidaceae & Orchis palustris Jacq. subsp. palustris / M & Çayırsalebi & 0 & 0.25 & 0.33 & 0.000 \\
\hline 12 & Plantaginaceae & Veronica gentianoides Vahl. subsp. gentianoides /D & Kandilçiçeği & 1 & 0.75 & 1.06 & 0.011 \\
\hline 13 & Polygonaceae & Polygonum bistorta L. / D & Çimeneveleği & 1 & 0.50 & 0.68 & 0.007 \\
\hline 14 & Primulaceae & Primula auriculata Lam. Tabl. / D & Felçotu & 3 & 0.25 & 0.40 & 0.012 \\
\hline 15 & Ranunculaceae & $\begin{array}{l}\text { Ranunculus dissectus M.Bieb. subsp. glabrescens (Boiss.) } \\
\text { P.H.Davis / D }\end{array}$ & Kösekebikeç & -1 & 1.50 & 2.09 & -0.021 \\
\hline 16 & Rosaceae & Alchemilla retinervis Buser/ D & Damarlıkeltat & 0 & 4.75 & 6.58 & 0.000 \\
\hline 17 & Rosaceae & Potentilla crantzii (Crantz) Fritsch / D & Beşparmakotu & 0 & 7.50 & 10.88 & 0.000 \\
\hline \multirow[t]{3}{*}{18} & Rosaceae & Sibbaldia parviflora Willd. var. parviflora / D & Findikotu & 1 & 4.00 & 5.75 & 0.058 \\
\hline & & & Toplam & & 29.75 & 42.14 & 0.386 \\
\hline & & & Genel toplam & & 70.75 & 100.00 & 2.383 \\
\hline
\end{tabular}

\section{Sonuç ve öneriler}

Sonuç olarak, yapılan çalışmada 6 Poaceae, 1 Fabaceae ve 18 tane de diğer familyadan bitkiler olmak üzere toplamda 15 familya ve 22 cins de, 25 takson tespit edilmiş olup, bunların 10 tanesi monokotil, 15 tanesi dikotil olarak belirlenmiştir. Mera bitkilerinin toprağı kaplama oranı \% 70.75, toprağı kaplama alanına göre botanik kompozisyonlar1 Poaceae \% 54.98, Fabaceae \% 2.88 ve diğer familyalar \% 42.14 oranında bulunmuştur. Meranın botanik kompozisyonunda bulunan bitkilerden Poaceae'den
K1lotu (Nardus stricta L.) (\% 30.25); Fabaceae'den Aküçgül (Trifolium repens L. var. repens) (\% 2.88) ve diğer familyalardan Beşparmakotu (Potentilla crantzii) (\% 10.88) taksonları ilk sırayı oluşturmaktadır. 2.383 mera derecesi ile meranın durumu zayıf olarak belirlenmiştir. $\mathrm{Bu}$ durumda zayıf olan merayı iyileştirmek için, meraya uygun ıslah yöntemi (kontrolsüz otlatmadan kaçınma, üstten tohumlama, gübreleme gibi) belirlenmesine yönelik çalışmalar yapılması sonucuna varılmıştır. 


\section{Kaynaklar}

Aydın, İ., Uzun, F., 2002. Çayır-mera amenajmanı ve 1slahı. Ondokuz Mayıs Üniversitesi Ziraat Fakültesi Ders Kitabı, No: 9, Samsun.

Babalık, A.A., Ercan, A., 2018. Eskişehir ili Karaören köyü merasının vejetasyon özelliklerinin belirlenmesi. Türkiye Ormancilık Dergisi, 19(3): 246-251.

Babalık, A.A., Sarıkaya, H., 2015. Isparta ili Zengi Merasında ot verimi ve botanik kompozisyonun tespiti üzerine bir araştırma. Türkiye Ormancılık Dergisi, 16(2): 96-101.

Bakoğlu, A., 1999. Otlatılan ve korunan iki farklı mera kesiminin bazı toprak ve bitki örtüsü özelliklerinin karșılaştırılması. Doktora tezi, Atatürk Üniversitesi, Fen Bilimleri Enstitüsü, Erzurum.

Bakoğlu, A., Baykal, H., Çatal, M.İ., 2019. Handüzü Yaylasının Botanik Kompozisyonu Üzerine Bir Çalışma. Turkish Journal of Agriculture - Food Science and Technology, 7(9): 13391343. DOI: https://doi.org/10.24925/ turjaf.v7i9.1339-1343. 2561.

Baykal, H., 2019. Flora of Akyamaç Waterfall natural park and environs (Rize/Turkey). Biological Diversity and Conservation, 12(1): 128-137.

Baykal, H., Atamov, V., 2016. Floristic diversity in Bashemsin Valley of Kackar Mountains National Park of Rize, Turkey. Pakistan Journal of Botany, 48(5): 1871-1876.

Baykal, H., Atamov, V., 2017. Ethnobotanical Documentation of Plants of Başhemşin Valley, Kaçkar Mountains National Park, Rize, Turkey. Bangladesh Journal of Botany, 46(2): 767-773.

Baykal, H., Atamov, V., 2018. Isırlık Doğa Parkı ve çevresinin floras1. Ot Sistematik Botanik Dergisi, 25(2): 151-170.

Baykal, H., Atamov, V., Yüksek, T., 2018. Flora of Tunca Valley Natural Park and Environs (Ardeşen-Rize/Turkey). Biological Diversity and Conservation, 11(3): 9-23.

Carlier, L., De Vliegher, A., Van Cleemput, O., Boeckx, P., 2005. Importance and functions of European grasslands. Communications in agricultural and applied biological sciences, 70(1): 5-15.

Çatal, M., Baykal, H., Bakoğlu, A., 2019. Ovit Yaylasının (İkizdere-RİZE) Botanik Kompozisyonunun Belirlenmesi. Journal of Anatolian Environmental and Animal Sciences, 4(3): 435-440. DOI: 10.35229/jaes.600149

Çınar, S., Hatipoğlu, R., Avc1, M., Yücel, C., İnal, İ., 2019. Adana İli Tufanbeyli İlçesi Meralarının Vejetasyon Yapısı Üzerine Bir Araştırma. Kahramanmaraş Sütçü İmam Üniversitesi Tarım ve Doğa Dergisi, 22(1): 143-152. DOI: 10.18016/ksutarimdoga.vi.448421

Çobanoğlu, M., 2012. Güneysu- Çağrankaya arası bölgenin flora ve vejetasyonu. Yüksek Lisans tezi, Recep Tayyip Erdoğan Üniversitesi, Fen Bilimleri Enstitüsü, Rize.

Davis, P.H., 1965-1985. Flora of Turkey and The East Aegean Islands, Vol. 1-9, Edinburgh University Press, Edinburgh.
Davis, P.H., Mill, R.R., Tan, K., 1988. Flora of Turkey and The East Aegean Islands, Vol. 10, Edinburgh University Press, Edinburgh.

De Vries, D.M., De Boer, T.A., Dirver, J.P.P., 1951. Evalation of grassland by botanical research in the Netherlands. In Proc. United National Sci. Conf. on the Conservation and Utilization of Resources, 6, 522-524.

Erik, S., Guner, A., Yıldırımlı, Ş., Sümbül, H., 1996. Tohumlu bitkiler sistematiği laboratuvar kılavuzu. Literatür Yayınevi, Ankara.

Gökkuş, A., 1994. Türkiye'nin Kaba Yem Üretiminde Çayır-Mera ve Yem Bitkilerinin Yeri ve Önemi. Atatürk Üniversitesi Ziraat Fakültesi Dergisi, 25(2): 250-261.

Gökkuş, A., Koç, A., Çomaklı, B., 1993. Çayır-mera uygulama kılavuzu. Atatürk Üniversitesi Ziraat Fakültesi Yayınları No:142, Atatürk Üniversitesi Ziraat Fakültesi Ofset Tesisi, Erzurum.

Güner, A., Aslan, S., Ekim, T., Vural, M., Babaç, M.T. (Eds.)., 2012. Türkiye Bitkileri Listesi (Damarlı Bitkiler). Nezahat Gökyiğit Botanik Bahçesi ve Flora Araştırmaları Derneği Yayını, İstanbul.

Güner, A., Özhatay, N., Ekim, T., Başer, K.H.C., 2000. Flora of Turkey. Vol. 11. Edinburgh University Press, Edinburgh.

İspirli, K., Alay, F., Uzun, F., Çankaya, N., 2016. Doğal Meralardaki Vejetasyon Örtüsü ve Yapısı Üzerine Otlatma ve Topografyanın Etkisi. Türkiye Tarımsal Araştırmalar Dergisi, 3(1): 14-22.

Okatan, A., Yüksek, T., 1997. Aşırı Otlatılan Mera Parsellerinde Adi Korunga (Onobrychis viciifolia Scop.)'nın Yetiştirilmesi ve Verim Potansiyeli Üzerine Araştırmalar. Türkiye 2. Tarla Bitkileri Kongresi, 22-25 Eylül, Samsun, s. 492-498.

RİTOM, 2018. Rize Mera Alanı. https://rize.tarim.gov.tr/ Menu/13/Ekonomi (Erişim: 24.03.2019).

Sürmen, M., Kara, E., 2018. Aydın ili ekolojik koşullarında farklı eğimlerdeki mera vejetasyonlarının verim ve kalite özellikleri. Derim, 35(1): 67-72. DOI:10.16882/derim.2018.343428

Süzen, A., 2017. Ambarlık Yaylası (Çamlıhemşin/Rize)'nın florası ve vejetasyonu. Yüksek Lisans tezi, Recep Tayyip Erdoğan Üniversitesi Fen Bilimleri Enstitüsü, Rize.

Tosun, F., 1968. Doğu Anadolu kıraç meralarının ıslahında uygulanabilecek teknik metodların tesbiti üzerine bir araştırma. Zirai Araştırma Enstitüsü Araştırma Bülteni No: 29, Ankara.

TÜGGM, 2008. Türkiye'nin çayır ve mera bitkileri. Tarım ve Köyişleri Bakanlığı, Tarımsal Üretim ve Geliştirme Genel Müdürlüğü Yayınları, $468 \mathrm{~s}$.

TÜIK, 2019. T.C. Başbakanlık Devlet Meteoroloji İşleri Genel Müdürlüğü, Rize İl Müdürlüğü Kayıtları.

TÜIK., 2019. Bitkisel Üretim İstatistikleri. http://www.tuik.gov.tr (Erişim: 30 Temmuz 2019).

Yavuz, T., Sürmen, M., 2016. Vegetation features of alpine and subalpine rangelands in Eastern Black Sea region. Scientific Papers Series A Agronomy, 54: 474-477. 